\title{
PENGGUNAAN METODE DISKUSI KELOMPOK GUNA MENINGKATKAN HASIL BELAJAR MATERI MENEMUKAN IDE BACAAN TEKS DI SMP
}

\author{
H. Masrik \\ Sekolah Menengah Pertama Negeri 3 Ketapang \\ Email: masriksmpn3@gmail.com
}

\begin{abstract}
Abstrak
Pemilihan masalah penulisan kajian makalah Ilmiah ini berdasarkan kenyataan bahwa hasil belajar siswa terhadap materi menemukan Ide Bacaan masih rendah. Padahal dengan dikuasainya pelajaran Bahasa Indonesia ini pada umum siswa tidak mengalami kesulitan untuk mempelajari mata pelajaran lainnya. observasi ini dilaksanakan pada bulan Januari s.d. Mei 2018, karena pada bulan-bulan tersebut peserta didik telah selesai ulangan umum dan berada di akhir semester sehingga kondisi siswa dapat diamati sejak awal. Metode Diskusi Kelompok adalah salah satu bentuk kegiatan yang dilaksanakan dalam bimbingan. Kegiatan diskusi kelompok merupakan kegiatan yang dilakukan dengan melibatkan lebih dari satu individu. Kegiatan diskusi kelompok ini dapat menjadi alternatif dalam membantu memecahkan permasalahan seorang individu. Dari penelitian ini dapat disimpulkan bahwa dengan adanya motivasi dalam pembelajaran metode pembelajaran Diskusi Kelompok tersebut kemampuan siswa terhadap materi menemukan ide bacaan dalam teks dan hasil-hasil belajar akan menjadi optimal. Makin tepat motivasi yang diberikan, akan makin berhasil pula pelajaran itu. Dengan motivasi yang tinggi maka intensitas usaha belajar siswa akan tinggi pula. Jadi motivasi akan senantiasa menentukan intensitas belajar siswa. Hal ini akan dapat meningkatkan Hasil belajar siswa.
\end{abstract}

\section{Kata Kunci: Diskusi Kelompok, Menemukan Ide Bacaan dalam Teks}

\section{PENDAHULUAN}

Standar kompetensi menemukan ide bacaan dalam teks dapat dinilai melalui kompetensi dasar memahami wacana tulis melalui kegiatan membaca intensif dan membaca memindai dalam Kurikulum Tingkat Satuan Pendidikan (KTSP) diajarkan di Kelas VII semester dua (genap) tahun 2018. Sebagian besar siswa Kelas VII SMPN 3 Ketapang tingkat menemukan ide bacaan dalam teks masih rendah khususnya dalam memahami wacana tulis melalui kegiatan membaca intensif dan membaca memindai. Hal ini ditunjukkan dengan gejala awal seperti berikut ini. Dari tes awal yang diberikan kepada siswa kelas VII, sebanyak 15 siswa atau sekitar $45,45 \%$ tidak mampu mendapat nilai kriteria ketuntasan minimum (KKM) yaitu 70 sedangkan pencapaian nilai rata-rata yaitu 68,13 . Hal ini diduga karena pembelajaran menemukan ide bacaan dalam teks masih mengacu pada metode pembelajaran konvensional yang masih berpusat pada guru, sehingga pembelajaran tidak menyenangkan dan membosankan bagi siswa. Agar dalam pembelajaran dapat menyenangkan dan bermakna, maka digunakan pendekatan yang mendukung dengan strategi pembelajaran yang sesuai.

Agar pembelajaran menemukan ide bacaan dalam teks menjadi pembelajaran yang menyenangkan dan bermakna, maka proses pembelajaran harus dibangun dengan cara yang sesuai seperti dengan sistem pembelajaran. Sistem pembelajaran ini berusaha memanfaatkan teman sejawat (siswa lain) sebagai sumber belajar, di samping guru dan sumber belajar lainnya. Melalui pembelajaran diskusi kelompok akan memberi kesempatan kepada siswa untuk bekerja sama dengan sesama siswa dalam tugas-tugas yang terstruktur. Diskusi kelompok adalah salah satu bentuk kegiatan yang dilaksanakan dalam bimbingan. Kegiatan diskusi kelompok merupakan 
kegiatan yang dilakukan dengan melibatkan lebih dari satu individu. Kegiatan diskusi kelompok ini dapat menjadi alternatif dalam membantu memecahkan permasalahan seorang individu serta dapat meningkatkan aktivitas siswa dalam proses pembelajaran dan membuat pembelajaran lebih bermakna serta berarti dalam kehidupan siswa. Hal ini dikarenakan adanya keterlibatan siswa dalam proses pembelajaran. Adanya keterlibatan intelektual emosional siswa melalui dorongan dan semangat yang dimilikinya. Keikutsertan siswa secara aktif dan kreatif dalam proses pembelajaran serta membina kerja sama antar siswa untuk mencapai tujuan pembelajaran.

Metode pembelajaran diskusi kelompok yang akan diterapkan yaitu metode diskusi kelompok. Metode pembelajaran diskusi kelompok memiliki kelebihan dan kekurangan. Adapun kelebihan dari metode pembelajaran kelompok diantaranya: (1) Metode diskusi melibatkan semua siswa secara langsung dalam proses belajar Mengajar, (2) Setiap siswa dapat menguji tingkat pengetahuan dan bahan pelajarannya masing - masing, (3) Metode diskusi dapat menumbuhkan dan mengembangkan cara berpikir dan sikap ilmiah. Sedangkan kekuranga dari metode pembelajaran diskusi kelompok diantaranya: (1) Suatu diskusi tak dapat diramalkan sebelumnya mengenai bagaimana hasilnya sebab tergantung kepada kepemimpinan sisiwa dan partisipasi anggotanya, (2) Suatu diskusi memerlukan keterampilan-keterampilan tertentu yang belum pernah dipelajari sebelumnya, (3) Jalannya diskusi dapat dikuasai (didominasi) oleh beberapa siswa yang "menonjol", (4) Tidak semua topik dapat dijadikan pokok diskusi, tetapi hanya hal-hal yang barsifat problematik saja yang dapat didiskusikan, (5) Diskusi yang mendalam memerlukan waktu yang banyak.

Teknik diskusi sebagai metode belajar mengajar lebih cocok dan diperlukan apabila kita (guru) hendak : (1) Memanfaatkan berbagai kemampuan yang ada (dimiliki) oleh para siswa, (2) Memberikan kesempatan kepada siswa untuk menyalurkan kemampuannya masing- masing,
Memperoleh umpan balik dari para siswa tentang apakah tujuan yang telah dirumuskan telah dicapai, (4) Membantu para siswa belajar berpikir teoretis dan praktis lewat berbagai mata pelajaran dan kegiatan sekolah, (5) Membantu para siswa belajar menilai kemampuan dan peranan diri sendiri maupun teman-temannya (orang lain), (6) Membantu para siswa menyadari dan mampu merumuskan berbagai masalah yang di "lihat" baik dari pengalaman diri sendiri maupun dari pelajaran sekolah, (7) Mengembangkan motivasi untuk belajar lebih lanjut. Adapun syarat-syarat pelaksanaan metode diskusi adalah: (1) Pendidik menguasai masalah yang didiskusikan secara utuh, (2) Pokok-pokok masalah yang didiskusikan agar dipersiapkan lebih awal., (3) Memberikan kesempatan secara bebas kepada peserta didik untuk mengajukan pikiran, pendapat atau kritikannya, (4) Masalah yang didiskusikan diusahakan agar tetap pada pokoknya.Dengan metode ini dimanfaatkan $54,54 \%$ siswa yang sudah mencapai kriteria ketuntasan minimal agar dapat berbagi dengan teman-temannya yang belum mencapai ketuntasan minimal. Oleh karena itu metode diskusi kelompok diharapkan dapat meningkatkan hasil belajar peserta didik. Menurut Wingkel (1991:36) “

Belajar adalah suatu aktivitas mental atau psikis yang berlangsung dalam interaksi aktif dengan lingkungan yang menghasilkan perubahan-perubahan dalam pengetahuan, pemahaman, keterampilan, nilai dan sikap, perubahan ini bersifat relative. Menurut S.Nasution (1995:52) Hasil belajar adalah sesuatu perubahan yang terjadi pada individu yang belajar, perilaku yang membentuk kecakapan, kebiasaan, sikap, pengertian, penguasaan dalam individu yang belajar.

Dalam observasi tindakan kelas ini yang dimaksud dengan hasil belajar siswa adalah hasil nilai ulangan harian yang diperoleh siswa dalam mata pelajaran Ilmu pengetahuan sosial Terpadu. Oleh karena itu observasi tindakan kelas ini untuk membuktikan bahwa melalui penerapan diskusi kelompok dapat meningkatkan aktivitas siswa dan hasil belajar dalam 
menemukan ide bacaan dalam teks dalam satu teks bacaan. Observasi ini dilaksanakan dengan tujuan: 1 . Untuk mengetahui penerapan metode diskusi kelompok dalam menemukan ide bacaan dalam teks. 2. Untuk mengetahui metode diskusi kelompok dalam meningkatkan hasil belajar siswa dalam menemukan ide bacaan dalam teks.

\section{METODE PENELITIAN}

Menurut pengertiannya penelitian tindakan adalah penelitian tentang hal-hal yang terjadi dimasyarakat atau sekelompok sasaran, dan hasilnya langsung dapat dikenakan pada masyarakat yang bersangkutan (Arikunto, 2002:82). Ciri atau karakteristik utama dalam penelitian tindakan adalah adanya partisipasi dan kolaborasi antara peneliti dengan anggota kelompok sasaran. Penelitian tidakan adalah satu strategi pemecahan masalah yang memanfaatkan tindakan nyata dalam bentuk proses pengembangan invovatif yang dicoba sambil jalan dalam mendeteksi dan memecahkan masalah. Dalam prosesnya pihak-pihak yang terlibat dalam kegiatan tersebut dapat saling mendukung satu sama lain.

Sedangkan tujuan penelitian tindakan harus memenuhi beberapa prinsip sebagai berikut: (1) Permasalahan atau topik yang dipilih harus memenuhi kriteria, yaitu benarbenar nyata dan penting, menarik perhatian dan mampu ditangani serta dalam jangkauan kewenangan peneliti untuk melakukan perubahan. (2) Kegiatan penelitian, baik intervensi maupun pengamatan yang dilakukan tidak boleh sampai mengganggu atau menghambat kegiatan utama. (3) Jenis intervensi yang dicobakan harus efektif dan efisien, artinya terpilih dengan tepat sasaran dan tidak memboroskan waktu, dana dan tenaga. (4) Metodologi yang digunakan harus jelas, rinci, dan terbuka, setiap langkah dari tindakan dirumuskan dengan tegas sehingga orang yang berminat terhadap penelitian tersebut dapat mengecek setiap hipotesis dan pembuktiannya. (5) Kegiatan penelitian diharapkan dapat merupakan proses kegiatan yang berkelanjutan (on-going), mengingat bahwa pengembangan dan perbaikan terhadap kualitas tindakan memang tidak dapat berhenti tetapi menjadi tantangan sepanjang waktu (Arinkunto, 2002:82-83).

Tempat penelitian adalah tempat yang digunakan dalam melakukan penelitian untuk memperoleh data yang diinginkan. Penelitian ini bertempat di SMP Negeri 3 Ketapang .Waktu penelitian adalah waktu berlangsungnya penelitian atau saat penelitian ini dilangsungkan. Penelitian ini dilaksanakan pada bulan januari sampai dengan mei semester ganjil tahun pelajaran 2018/2019. Subyek penelitian adalah siswasiswi Kelas VII SMP Negeri 3 Ketapang pada pokok bahasan menemukan ide bacaan dalam teks.

Penelitian ini dilaksanakan melalui 2 tahap, yaitu, tahap 1 meliputi (1) tahap perencanaan, (2) tahap pelaksanaan, (3) tahap pengamatan, dan (4) tahap refleksi dan perencanaan ulang. Pada tahap perencanaan ini kegiatan yang dilakukan meliputi, (1) melakukan analisis kurikulum untuk mengetahui kompetensi dasar yang akan disampaikan kepada siswa dalam pembelajaran (2) Membuat rencana pembelajaran dengan mengacu pada tindakan yang diterapkan dalam observasi, (3) Menentukan kompetensi dasar yang akan diajarkan yaitu menemukan ide bacaan dalam teks, (4) Membuat lembar kerja siswa (LKS), menyiapkan lembar pengamatan, lembar evaluasi dan daftar nama serta absensi siswa, (5) Menyiapkan sumber belajar seperti bukubuku teks dan kertas karton untuk media model pembelajaran Diskusi kelompok.

\section{HASIL DAN PEMBAHASAN}

Sebelum dilaksanakan observasi, motivasi siswa dalam pembelajaran bahasa indonesia masih rendah. Dari observasi yang telah dilakukan terhadap aktifitas siswa ketika proses pembelajaran berlangsung, siswa yang berperan secara aktif dalam proses pembelajaran itu baik dalam bentuk interaksi antar siswa maupun siswa dengan pengajar, ternyata dari seluruh siswa kelas VII yang berjumlah 33 orang hanya 18 orang siswa atau $54,54 \%$ saja yang aktif, sedangkan 
15 orang siswa atau $45,45 \%$ lainnya tidak aktif.

Dalam pembelajaran metode Diskusi kelompok dilakukan dua kali pertemuan setiap tahapan sebagai berikut: Tahapan I meliputi: Tahapan perencanaan yaitu: (1) melakukan analisis kurikulum untuk mengetahui kompetensi dasar yang akan disampaikan kepada siswa dalam pembelajaran, (2) Membuat rencana pembelajaran dengan mengacu pada tindakan yang diterapkan dalam observasi, (3) Menentukan kompetensi dasar yang akan diajarkan yaitu menemukan ide bacaan dalam teks, (4) Membuat lembar kerja siswa (LKS), menyiapkan lembar pengamatan, lembar evaluasi dan daftar nama serta absensi siswa, dan (5) Menyiapkan sumber belajar seperti buku-buku teks dan kertas karton untuk media model pembelajaran Diskusi kelompok.

Tahap Pelaksanaan yaitu pelaksanaan prosedur atau langkah-langkah pembelajaran diskusi kelompok adalah sebagai berikut: (1) Memilih tema yang cukup menarik untuk disampaikan, (2) Memperkenalkan bentuk dan jenis komunikasi dengan Bahasa Indonesia setara level novice pada peserta didik menjelaskan poin-poin kunci atau masalah-masalah pokok yang diangkat, (3) Ketika pembelajaran berjalan, hentikan dibeberapa tempat untuk menekan poin-poin tertentu, memunculkan beberapa pertanyaan atau berilah contoh-contoh, meminta peserta didik untuk menjelaskan poin-poin yang telah ditentukan, meminta pada peserta didik membuat beberapa pertanyaan pada poinpoin tersebut tentang materi pelajaran Bahasa Indonesia dengan media gambar, (4) Melanjutkan proses itu selama masih ada waktunya memungkinkan hingga waktu yang ditentukan habis.

Pada awal pelaksanaan tindakan tahapan 1 belum sesuai dengan rencana masih terdapat beberapa kekurangan dalam pelaksanaan kegiatan belajar mengajar terutama dalam penggunaan strategi metode Diskusi kelompok sehingga interaksi antara guru - siswa, siswa - siswa agak terganggu meskipun telah melaksanakan dengan optimal. Pelaksanaan tindakan tahapan 1 suasana kelas kurang tertib. Hal tersebut disebabkan: (1) Adanya suasana kelas yang agak lain dari biasanya karena kehadiran penulis / observer di kelas, (2) Kerena metode Diskusi kelompok merupakan hal yang baru bagi siswa sehingga guru agak kewalahan mengatur siswa yang akan maju ke depan unuk menyelesaikan soal, (3) Sebagian siswa belum terbiasa dengan kondisi belajar dengan metode Diskusi kelompok, (4) Sebagian siswa belum memahami pembelajaran metode Diskusi kelompok secara utuh dan menyeluruh.

Untuk mengetahui hal tersebut dilakukan upaya sebagai berikut: (1) Guru dengan intensif memberikan pengertian kepada siswa tentang metode Diskusi kelompok keikut sertaan setiap siswa untuk mempelajari materi Bahasa Indonesia, (2) Guru membantu memahami langkah-langkah pembelajaran metode Diskusi kelompok. Tahap Pengamatan (observasi) : Pengamatan ini dilakukan terhadap; (1) Situasi kegiatan belajar mengajar, (2) Minat siswa, dan (3) Kemampuan siswa dalam memahami materi pembelajaran. Minat Siswa Berdasarkan hasil observasi yang telah dilakukan dalam tahapan 1 kegiatan pelaksanaan tindakan kelas diperoleh data bahwa minat siswa dalam membaca Bahasa Indonesia mengalami kenaikan, sebelum observasi prosentase minat siswa adalah 75,75\%. Angka tersebut berdasarkan hasil ulangan harian dan hasil observasi penulis terhadap minat peserta didik dalam poses pembelajaran Bahasa Indonesia.

Aktivitas Guru Hasil observasi aktivitas guru dalam proses pembelajaran pada tahapan I masih tergolong rendah dengan perolehan skor 25 atau $75,75 \%$ sedangkan skor idealnya adalah 40. Hal ini terjadi karena guru lebih banyak membaca sendiri dan kurang memberikan kesempatan kepada peserta didik untuk melakukan sendiri untuk membaca secara kooperatif membaca keras (Diskusi kelompok). Selanjutnya Ketuntasan belajar siswa, refleksi evaluasi tahapan I Penguasaan peserta didik terhadap materi pelajaran pun, asih tergolong kurang dari 
skor ideal 100 skor perolehan rata-ratanya hanya mencapai 72,27 atau sekitar 75,75\%.

Namun telah mengalami kenaikan dari sebelum dilaksanakan observasi dimana hasil pre test yang rata-ratanya hanya 68,13 mengalami kenaikan menjadi 72,27 pada post test tahapan I. Dari pengamatan awal ini selanjutnya dilakukan refleksi dari berbagai sudut diantaranya : pengaruh guru, metode pembelajaran, sikap dan perilaku siswa. Berdasarkan hasil refleksi tersebut dapat disimpulkan bahwa kemampuan siswa kelas VII dalam menemukan ide bacaan dalam teks dengan diskusi kelompok pada mata pelajaran Bahasa Indonesia masih kurang. Berdasarkan data hasil pengamatan terhadap pelaksanaan proses pembelajaran pada tahapan I ini, terdapat temuan-temuan sebagai berikut: (1) Hasil Belajar Bahasa Indonesia siswa secara individu dalam proses pembelajaran masih lemah $(75,75 \%)$ karena motivasi siswa masih rendah (2) Hampir semua siswa belum menunjukkan perkembangan kemampuan Bahasa Indonesia -nya dan masih belum ada yang memperoleh nilai sangat baik (maksimal) terutama pada aspek komunikasi, kerja sama dan percaya diri (3) Semua kelompok belum menunjukkan perkembangan kemampuan Bahasa Indonesianya dengan kategori baik dan sangat baik dan kinerja kelompok belum bagus, (4) Aspek empati siswa semuanya belum muncul, semua siswa belum mempunyai rasa kebersamaan, menghargai orang lain, menghagai pelajaran, mau berbagi dan menerima masukan dari teman. Secara individu, baru dari $75,75 \%$, hasil belajar Bahasa Indonesia siswa belum berkembang dan belum menunjukkan peningkatan yang berarti, baik secara kelompok maupun individu.

Tahap Refleksi dan Perencanaan Ulang: Adapun keberhasilan dan kegagalan yang terjadi pada tahapan I sebagai berikut: (1) Guru belum terbiasa menciptakan suasana pembelajaran yang mengarah kepada pendekatan pembelajaran metode Diskusi kelompok mereka merasa senang dan antusias untuk belajar. Hal ini bisa dilihat dari hasil observasi terhadap minat siswa dalam proses pembelajaran hanya mencapai $75,75 \%$, (2) Sebagian siswa belum terbiasa dengan kondisi belajar dengan menggunakan pembelajaran metode Diskusi kelompok mereka merasa senang dan antusias untuk belajar. Hal ini bisa dilihat dari observasi terhadap aktivitas siswa dalam proses pembelajaran hanya mencapai rata-rata $72,27 \%$, (3) Hasil evaluasi tahapan I mencapai $75,75 \%$, (4) Masih ada siswa yang belum bisa menyelesaikan tugas dengan waktu yang ditentukan. Hal ini karena siswa tersebut kurang serius dalam belajar, (5) Masih ada siswa yang kurang mampu. Untuk memperbaiki kelemahan dan mempertahankan keberhasilan yang telah dicapai pada tahapan pertama, maka pada pelaksanaan tahapan kedua dapat dibuat perencanaan sebagai berikut: (1) Memberikan motivasi kepada siswa yang mengalami kesulitan, (2) Lebih intensif membimbing siswa yang mengalami kesulitan, (c) Memberikan pengakuan atau penghargaan (reward).

Tahapan II meliputi tahap perencanaan: perencanaan tahapan kedua berdasarkan replaning tahapan pertama, sebagai berikut: (1) Memberikan motivasi kepada siswa agar lebih aktif dalam pembelajaran, (2) Lebih intensif membimbing siswa yang mengalami kesulitan, (3) Memberikan pengakuan atau penghargaan reward), (4) Membuat perangkat pembelaljaran kooperatif tipe metode Diskusi kelompok yang lebih mudah difahami oleh peserta didik. Tahap Pelaksanaan: Penulis masih menerapkan tindakan yang mengacu pada scenario model pembelajaran metode Diskusi kelompok dengan prosedur atau langkah-langkah pembelajaran yang telah ditentukan dalam pelaksanaan pada tahapan 1.Dengan keadaan sebagai berikut: (1) Suasana pembelajaran sudah mengarah kepada pembelajaran metode Diskusi kelompok. Tugas yang diberikan guru kepada siswa dengan menggunakan lembar 18 kerja akademik maupun dikerjakan dengan baik. Setiap siswa menunjukkan saling membantu untuk menguasai materi pelajaran yang telah 
diberikan melalui tanya jawab atau diskusi didik termotivasi untuk bertanya dan menanggapi suatu presentasi dari guru, (3) Suasana pembelajaran yang efektif dan menyenangkan sudah mulai tercipta, (4) Siswa lebih antusias mengikuti proses belajar mengajar di kelas. Tahap Pengamatan (observation): Adapun hasil observasi pada tahapan II ini dapat dijabarkan sebagai berikut: (1) Keaktifan Siswa Berdasarkan hasil observasi yang telah dilakukan dalam tahapan II kegiatan pelaksanaan tindakan kelas diperoleh data bahwa minat siswa dalam memahami pelajaran menemukan ide bacaan dalam teks melalui metode diskusi kelompok mengalami peningkatan hasil belajar siswa. Setelah diadakan observasi pada tahapan I persentase keaktifan siswa adalah $75,75 \%$ setelah diadakan observasi tahapan II menjadi 90,90\%, (2) Aktivitas Guru Hasil observasi aktivitas guru dalam proses pembelajaran pada tahapan II mendapat skor 35 atau 90,90\% sedangkan skor idealnya adalah 40 atau $100 \%$. Hal ini menunjukkan adanya peningkatan yang sangat signifikan, (3) Ketuntasan belajar siswa, refleksi evaluasi tahapan II Penguasaan peserta didik terhadap materi pelajaran pun, menunjukkan peningkatan dari skor ideal 100 dengan rata-rata 72,27 bacaan dalam teks dengan metode diskusi kelompok dengan kategori baik dan sangat baik dan kinerja kelompok sudah bagus, (4) Aspek empati siswa semuanya telah muncul, semua siswa sudah mempunyai rasa kebersamaan, enghargai orang lain, menghagai pelajaran, mau berbagi dan menerima masukan dari teman. Secara individu, sudah 90,90\%, kemampuan Bahasa Indonesia siswa telah berkembang dan sudah antara sesama siswa, (2) Sebagian peserta mengalami kenaikan menjadi 81,96. Hasil ulangan harian setelah menggunakan pembelajaran Diskusi kelompok juga mengalami peningkatan yang sangat signifikan, sedangkan sebelumnya hanya 75,75\%.Dari hasil analisis data tentang tingkat kemampuan menemukan ide bacaan dalam teks dengan metode diskusi kelompok siswa pada suklus II mengalami peningkatan. Dengan demikian dapat ditarik kesimpulan bahwa kemampuan siswa dalam membaca (reading) dengan Bahasa Indonesia dapat meningkat. Berdasarkan data hasil pengamatan terhadap pelaksanaan proses pembelajaran pada tahapan II ini, terdapat temuan-temuan sebagai berikut: (1) Kemampuan membaca dengan Bahasa Indonesia siswa secara individu dalam proses pembelajaran sangat baik $(90,90 \%)$ karena motivasi siswa cukup tinggi, (2) Hampir semua siswa telah menunjukkan perkembangan kemampuan menemukan ide bacaan dalam teks dengan metode diskusi kelompok dan sudah ada yang memperoleh nilai sangat baik (maksimal) terutama pada aspek komunikasi, kerja sama dan percaya diri, (3) Semua kelompok telah menunjukkan perkembangan kemampuan menemukan ide

Berdasarkan hasil penulisan, hsil belajar siswa yang diamati pada aspek komunikasi, kerja sama, percaya diri, dan empati menunjukkan peningkatan dari kondisi awal, tahapan I, dan tahapan II. Hasil tahapan tindakan pada tahapan I sekaligus dibandingkan dengan hasil pada tahapan II, disajikan pada pada tabel berikut.

Tabel 1 Perbandingan Persentase Perkembangan Bahasa Indonesia Jumlah Kelompok Minimal Kategori Baik Tahapan I Dan Tahapan II

\begin{tabular}{lll}
\hline Kelompok & Tahapan I & Tahapan II \\
\hline Persentase & $75,75 \%$ & $90,90 \%$ \\
\hline
\end{tabular}


Berdasarkan Tabel 1, terlihat bahwa secara kelompok setiap kelompok telah melaksanakan proses pembelajaran Bahasa Indonesia dengan baik yang berarti mereka telah melaksanakan pembelajaran Diskusi kelompok dengan baik pula dan kemampuan Bahasa Indonesia siswa secara kelompok dapat berkembang secara baik. Hal ini ditunjukkan pada tahapan II, yakni rata-rata skor kelompok untuk 4 komponen Bahasa Indonesia berkisar antara 3,00 sampai 4,50. Dua kelompok berkategori baik dan tiga kelompok berkategori sangat baik. Lebih dari $85 \%$ siswa secara kelompok sudah menunjukkan perkembangan kemampuan Bahasa Indonesianya.

Berdasarkan Tabel 1, terjadi peningkatan rata-rata kemampuan Bahasa Indonesia jumlah siswa secara kelompok sebesar 15,15\% dari tahapan I ke tahapan II. Ini berarti dari kategori baik pada tahapan I, meningkat menjadi kategori sangat baik pada tahapan II.

\section{Tabel 2 Perbandingan Rerata Keempat Aspek Bahasa Indonesia Siswa Pada} Tahapan I dan Tahapan II Secara Kelompok

\begin{tabular}{lllll}
\hline Indikator & Komonikasi & Kerja Sama & Percaya Diri & Empati \\
\hline Tahapan I & 3,50 & 3,50 & 3,33 & 3,67 \\
\hline Kategori & Baik & Baik & Baik & Baik \\
\hline Tahapan II & 4,17 & 4,00 & 3,50 & 4,50 \\
\hline Kategori & Sangat Baik & Sangat Baik & Sangat Baik & Sanngat Baik \\
\hline
\end{tabular}

Bedasarkan Tabel 2, terjadi peningkatan rata-rata aspek kemampuan Bahasa Indonesia siswa secara kelompok dari tahapan I ke tahapan II yaitu komunikasi, kerja sama, dan empati dari kategori baik menjadi kategori sangat baik, sedangkan percaya diri skor reratanya naik dan masih berkategori baik.

\section{SIMPULAN DAN SARAN \\ Simpulan}

Berdasarkan hasil pembahasan yang telah disampaikan di atas, dapat disimpulkan sebagai berikut : (1) Penerapan Metode pembelajaran diskusi kelompok dapat meningkatkan pembelajaran menemukan ide bacaan dalam teks pada siswa kelas VII SMPN 3 Ketapang. (2) Metode pembelajaran diskusi kelompok dapat melibatkan siswa secara aktif dalam proses pembelajaran menemukan ide bacaan dalam teks pada siswa kelas VII SMPN 3 Ketapang. Metode pembelajaran diskusi kelompok dapat meningkatkan hasil belajar siswa kelas VII SMPN 3 Ketapang.

\section{Saran}

Berdasarkan apa yang telah disampaikan di atas, peneliti mengemukakan saran sebagai berikut : (1)Metode diskusi kelompok dapat digunakan dalam materi pembelajaran Bahasa Indonesia yang lain dan guru harus dapat menggunakan metode ini sesuai dengan kebutuhan pembelajaran yang ingin dicapai (2) Dalam proses melaksanakan metode diskusi kelompok harus membuat langkahlangkah pembelajaran yang tepat dan menarik sehingga siswa termotivasi untuk bekerja sama. Guru hendaknya selalu berusaha meningkatkan pengetahuan dan kemampuannya dalam proses belajar mengajar. Berusahalah selalu kreatif dalam mengajarkan materi pembelajaran.

\section{DAFTAR PUSTAKA}

Suharjono. 2011. Observasi di Kelas, Malang: Cakrawala Indonesia.

Suprijono, Agus. 2010. Diskusi Kelompok: Teori dan Aplikasi PIKEM, Jogyakarta: Pustaka Pelajar. 
Suwardi, Sarwiji, 2010. Observasi Tindakan Kelas dan Penelitian Karya Ilmiah, Surakarta: Yuma Pustaka.

Suyanto, 2009. Menjelajah Pembelajaran

Inovatif, Sidoarjo: Mamedia Buana Pusaka.
Tarigan, Hendri Guntur. 2009. Pengajaran Kompetensi Bahasa, Bandung: Bandung Angkasa.

Triatno.2007.Metode-metode Pembelajaran Inovatif berorentasi Konstruktivistik, Jakarta: Prestasi 